\title{
An Empirical Study of the Impact of Flipped Classroom on College Students' Autonomous Learning Ability
}

\author{
Wu Jing ${ }^{1,}$, Lin Yun ${ }^{2, b}$ \\ 1,2 Jiangxi Institute of Economic Administrators, Nanchang, Jiangxi, 330088 China \\ a20647795@qq.com, b46983725@qq.com
}

Keywords: Flipped classroom; College teaching; Teaching program; Quasi experiment

\begin{abstract}
Flipped Classroom” is essentially a teaching philosophy which is the theoretical basis for teaching flip design and flip teaching. The effect of flipped classroom teaching philosophy on the college teaching effectiveness is tested in this study. And the teaching procedure is used as the experimental variable to conduct teaching experiments.
\end{abstract}

\section{Introduction}

"Flipped Classroom" is essentially a teaching philosophy, and its most distinctive feature is the requirement to break and reorganize traditional classroom teaching procedures in the teaching practice. The teaching procedure is one aspect of teaching design and the traditional classroom teaching program is based on the teaching idea which is centered on the mode of teaching. The idea of the teaching-centered teaching concept comes into being after the shortcomings of traditional teaching have become increasingly prominent. But the teaching design can not be effectively implemented in practice because of the neglect of the teachers' leading role. In this sense, the teaching concept of flipped classroom just overcomes all the shortcomings, which not only satisfies the value appeal of "student-centered" and "consideration into efficiency and quality", but also lays emphasis on the leading role of teachers in the teaching process and the organization of teaching activities. Flipped classroom (FCM) can motivate students to control their study well and save more classroom time for meaningful interaction. It is popular in teaching classes like mathematics, science and procedural knowledge. As long as the technology is applied properly, students seem more receptive to classroom interaction and individual guidance.

\section{An Empirical Study of the Impact of Flipped Classroom on College Students' Autonomous Learning Ability}

A. Teaching Procedure Design

\begin{tabular}{|c|c|c|c|}
\hline $\begin{array}{l}\text { Teaching } \\
\text { Concepts }\end{array}$ & $\begin{array}{l}\text { Frame of } \\
\text { Reference }\end{array}$ & $\begin{array}{c}\text { Basic Steps of the } \\
\text { Teaching } \\
\text { Procedure }\end{array}$ & Framework and Features \\
\hline $\begin{array}{l}\text { Teaching-c } \\
\text { entered }\end{array}$ & $\begin{array}{c}\text { Traditional } \\
\text { Teaching }\end{array}$ & $\begin{array}{l}\text { Operation } \\
\text { demonstration-Di } \\
\text { stribution to } \\
\text { explain-Imitation } \\
\text { exercise-Individu } \\
\text { al counseling } \\
\end{array}$ & $\begin{array}{l}\text { The method that teachers are taken as } \\
\text { the center and "Imitation-Exercise" as } \\
\text { the main teaching method is conducive } \\
\text { to controlling the classroom, but } \\
\text { cannot respect individual differences } \\
\text { in ability levels between students. }\end{array}$ \\
\hline $\begin{array}{l}\text { Learning-c } \\
\text { entered }\end{array}$ & $\begin{array}{l}\text { Quasi } \\
\text { flipped } \\
\text { teaching }\end{array}$ & $\begin{array}{c}\text { Self-study } \\
\text { video-Imitation } \\
\text { exercise-Question } \\
\text { and } \\
\text { Answer-Individua }\end{array}$ & $\begin{array}{l}\text { The method of student-centered } \\
\text { teaching as well as students' } \\
\text { self-learning is highly conducive to the } \\
\text { development of the students' } \\
\text { autonomous learning ability, but is }\end{array}$ \\
\hline
\end{tabular}




\begin{tabular}{|c|c|c|c|}
\hline & l counseling & $\begin{array}{c}\text { detrimental to the students' ability to } \\
\text { interact. }\end{array}$ \\
\hline $\begin{array}{c}\text { Flipped } \\
\text { Classroom }\end{array}$ & $\begin{array}{c}\text { Flipped } \\
\text { teaching } \\
\text { video-Discovery- } \\
\text { Cooperative } \\
\text { learning- } \\
\text { Individual } \\
\text { counseling }\end{array}$ & $\begin{array}{c}\text { The method of student-centered } \\
\text { teaching, independent learning and } \\
\text { cooperative learning is helpful for the } \\
\text { development of students' ability of } \\
\text { independent exploration and } \\
\text { cooperative learning, but is not } \\
\text { beneficial to the teachers' teaching } \\
\text { control. }\end{array}$ \\
\hline
\end{tabular}

The teaching procedures of the three frameworks consist of four basic steps, but these are only the basic flow of teaching one knowledge (skill) point. It is necessary to circulate this basic process to complete the teaching of multiple knowledge (skill) points in the classroom.

In this experiment, 3 classes of students who are majored in business English and enrolled in 2016 from Foreign Language Department in Jiangxi Institute of Economic Administrators were used as experimental subjects. The test is based on the English Visual-Audio- Oral course. Among them, class 1 is the object of traditional teaching, class 2 is the object of Quasi flipped teaching, and class 3 is the object of flipped teaching.

\section{B. Research Method}

The first method is questionnaire. In order to comprehensively examine the effect of classroom teaching, we observe the teaching effect from the perspective of learning, according to the learning dimension theory of Dr. Knud Iyleres, a Danish psychologist. And on this basis, we design basic dimensions of "Questionnaire on the Effectiveness of Classroom Teaching in the University". Generally speaking, Professor Knudz argues that learning involves at least three dimensions of the factors, namely motivation, content, and interaction. According to the three dimensions of learning and taking into account its social context, four basic dimensions of designing the questionnaire are adopted, including "learning motivation and attitude", "learning content and resources", "learning environment and activities", and "teachers' behavioral performance”. Five to six questions are designed for each dimension with a total of 22 questions, and the answer to the question is designed by using Likert's fifth-grade scoring system. In order to ensure the validity of the questionnaire, 15 students are picked from three experimental groups to conduct a preliminary survey with each group five students after the completion of the questionnaire. Based on the feedback, experts are invited to make corrections and the questionnaire is revised. The second one is interview. Students are interviewed for many times in formal or random forms in and after the teaching process for the purpose of learning about their different viewpoints on the teaching effects from the perspective of individual differences. The third is the paper test which aims to know whether students have a good command of the concept and the theoretical knowledge after the teaching. The test covers most of the basic concepts involved in the course teaching.

\section{Questionnaire Data}

The descriptive statistical data from Table 2 indicates that the numerical ranges of mean value and standard deviation show an increasing trend in all dimensions from the "traditional teaching group”, “quasi flipped teaching group” to "flipped teaching group”. This explains that students' recognition degree of "flipped teaching" is higher than that of "traditional teaching". At the same time, the data shows that students' recognition degree for "flipped teaching" is higher than that of "quasi flipped teaching".

Table 2 Descriptive Statistics on the Influence of Three Teaching Procedure Designs on the College Teaching Effectiveness

\begin{tabular}{|c|c|c|c|c|c|}
\hline & $\begin{array}{c}\text { Learning } \\
\text { motivation } \\
\text { and attitude }\end{array}$ & $\begin{array}{c}\text { Learning } \\
\text { content and } \\
\text { resources }\end{array}$ & $\begin{array}{c}\text { Learning } \\
\text { environment } \\
\text { and activities }\end{array}$ & $\begin{array}{c}\text { Teachers' } \\
\text { performance }\end{array}$ & $\begin{array}{c}\text { Overall } \\
\text { evaluation }\end{array}$ \\
\hline $\begin{array}{c}\text { Traditional } \\
\text { teaching group }\end{array}$ & $18.06 \pm 2.59$ & $17.09 \pm 2.43$ & $13.78 \pm 2.01$ & $15.97 \pm 1.82$ & $64.91 \pm 6.52$ \\
\hline
\end{tabular}




\begin{tabular}{|c|c|c|c|c|c|}
\hline $\begin{array}{c}\text { Quasi-flip } \\
\text { teaching group }\end{array}$ & $19.66 \pm 1.60$ & $18.28 \pm 2.23$ & $15.59 \pm 2.08$ & $16.50 \pm 1.92$ & $70.03 \pm 5.68$ \\
\hline $\begin{array}{c}\text { Flipped } \\
\text { teaching group }\end{array}$ & $20.82 \pm 1.70$ & $19.94 \pm 1.90$ & $16.36 \pm 1.83$ & $17.42 \pm 1.64$ & $74.55 \pm 5.44$ \\
\hline
\end{tabular}

Statistical analysis of variance from Table 3 shows that there are significant differences among the five sources of variation in the three groups, which shows that the use of "traditional teaching", "quasi-flip teaching", and "flipped teaching "three kinds of teaching program design make big differences to the three classes. Post hoc tests (LSD) illustrates that the results of the questionnaire can explain the teaching effect of the "flipped teaching" better than "quasi-flip teaching", and the teaching effect of "traditional teaching" worse than "quasi-flip teaching" and "flipped teaching".

Table 3 Analysis of Variance of Three Kinds of Teaching Programs on the teaching effects on Different Groups. (N=97)

\begin{tabular}{|c|c|c|c|}
\hline $\begin{array}{c}\text { Sources of } \\
\text { Variation }\end{array}$ & MS & D f & F \\
\hline $\begin{array}{c}\text { Learning } \\
\text { motivation and } \\
\text { attitude }\end{array}$ & 62.1 & 2 & $15.36^{*}$ \\
\hline $\begin{array}{c}\text { Learning content } \\
\text { and resources }\end{array}$ & 66.49 & 2 & $13.79^{*}$ \\
\hline $\begin{array}{c}\text { Learning } \\
\text { environment and } \\
\text { activities }\end{array}$ & 56.87 & 2 & $5.47^{*}$ \\
\hline $\begin{array}{c}\text { Teachers' } \\
\text { behavioral } \\
\text { performance }\end{array}$ & 17.67 & 2 & \\
\hline
\end{tabular}

Note: ${ }^{*} \mathrm{p}<0.05, * * \mathrm{p}<0.01$ 。

Learners' views on FCM mode from the different types are analyzed via questionnaire. Secondly, the opinions of different types of learners on the academic burden of FCM are also investigated through questionnaire.

Table 4 The learners' Views on FCM Mode

\begin{tabular}{|c|c|c|c|c|}
\hline English Level & like very much & like & Not to matter & Dislike \\
\hline poor & $6.10 \%$ & $10.40 \%$ & $17.20 \%$ & $37.50 \%$ \\
\hline Medium & $12.20 \%$ & $31.40 \%$ & $25.60 \%$ & $20.60 \%$ \\
\hline excellent & $15.70 \%$ & $39.00 \%$ & $27.50 \%$ & $19.50 \%$ \\
\hline
\end{tabular}

Table 5 The learners' Views on Academic Burden in the FCM Mode

\begin{tabular}{|c|c|c|c|c|}
\hline English Level & Very heavy & Heavy & Suitable & Easy \\
\hline poor & $28.10 \%$ & $46.90 \%$ & $20.60 \%$ & $1.60 \%$ \\
\hline Medium & $24.50 \%$ & $40.20 \%$ & $23.40 \%$ & $14.70 \%$ \\
\hline excellent & $23.20 \%$ & $25.60 \%$ & $23.20 \%$ & $18.30 \%$ \\
\hline
\end{tabular}

Table 6 The learners' Views on Class Discussion in the FCM Mode

\begin{tabular}{|c|c|c|c|c|}
\hline English Level & Great help & Helpful & No help & Inadaptable \\
\hline poor & $10.90 \%$ & $39.20 \%$ & $21.60 \%$ & $9.80 \%$ \\
\hline Medium & $30.40 \%$ & $37.50 \%$ & $15.60 \%$ & $9.40 \%$ \\
\hline excellent & $37.80 \%$ & $39.00 \%$ & $13.40 \%$ & $8.80 \%$ \\
\hline
\end{tabular}

From the perspective of learner's analysis, students who have a good command of basic knowledge can adapt quickly to FCM teaching mode, and can achieve better results in this model.

\section{Interview Results}

According the interview date, most students in the traditional teaching group believe that the classroom teaching atmosphere is dull, and feel more and more boring about the learning content. 
However, the students in the "Flipped Teaching Group" express the opposite views. They believe if you have a strong learning interest, you will have a sense of achievement in mastering the knowledge and skills you have learned. It indicates that the flipped classroom has more advantages than the traditional teaching methods and can stimulate their learning motivation. Students in the quasi flipped teaching group hold that the teaching process is too fast to mastering the content, while the flipped teaching group seems to be easier to adapt to this teaching schedule.

\section{E. Exam Results}

After the teaching, a paper test is carried out in terms of the concept principles of the three groups and counted the test scores. We divided students into three grades: "poor" means less than 70 points, "medium" stands between 70 to 85 points, and "excellent" refers to 85 points and above .The statistical results of each group students are shown in the Figure 1.

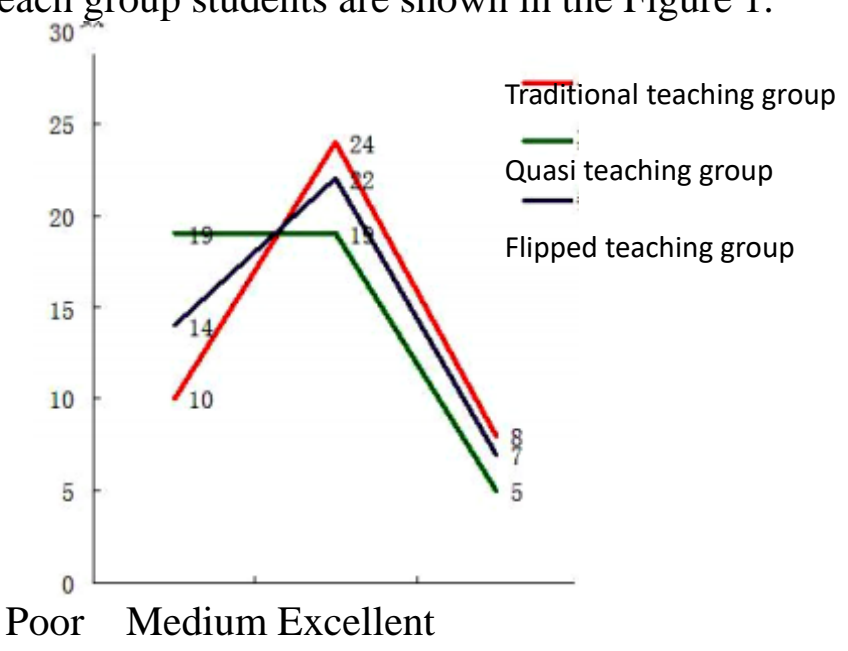

Figure 1 A Comparison Chart of Student Number with Different Scores

from the Three Experimental Groups

\section{Improvement of Comprehensive Abilities in the Flipped Classroom}

By implementing the flipped classroom and tracking survey in colleges and universities, it is found that there is a strong correlation between flipped classroom and college students' comprehensive abilities. Students who actively participate in the flipped classroom generally have high comprehensive abilities.

First, the ability of autonomous learning. Flipped classroom emphasizes the autonomy of learning and the ability to control the environment. Its teaching mode can make college students at their own pace access to educational resources, provide students with a lot of direct experience, and effectively improve the sense of self-efficacy of autonomous learning. This autonomous learning ability is conducive to enhancing the comprehensive quality of college students, making them able to adapt to challenging work environments which require continuous learning and improvement.

Second, the problem-solving ability. The ability to solve problems can be improved through flipped classroom. Flipped classroom is conducive to cultivating the critical thinking and promoting the ability to solve problems of college students. It helps college students develop good problem-solving skills. When facing some complex situation, they can find solutions independently.

Third, the teamwork and communication abilities. In the flipped classroom, each student can obtain knowledge from other students. Helping each other is conducive to understanding the course content faster, and they will have a deeper understanding of the abstract concept. In class, students from different backgrounds can effectively solve the problems of teachers' limited interaction with them and students' passive learning situations by cooperating and communicating with each other. Self-learning skills, such as cooperation and discussion, can strengthen students' sense of participation, thus encouraging students to explore deeper learning interests.

Fourth, improving creativity. In the teaching practice, the college students often feel very proud when they have the opportunity to develop or prove their creativity. In the flipped classroom, students' creative thinking is greatly promoted by providing a large number of videos and 
demonstrations, especially in terms of fluency, flexibility and novelty. Flipped classroom helps students develop creative thinking through higher-order thinking skills.

\section{Conclusion}

As a kind of new teaching mode, the FCM not only innovates the teaching way, but also flips the traditional teaching structure, teaching method and teaching mode. It establishes a relatively thorough "student-centered" teaching method. In this mode, students truly become the main body of learning, while the teacher is the organizer, helper and mentor. FCM is a typical "student-centered" learning mode, which gives full play to learners' subjective initiative. FCM is beneficial for learners to autonomously explore and develop discovery learning. It plays an important role in training and cultivating learners' autonomous learning ability, which is conducive to the cultivation of exploration ability and innovation ability. Compared with traditional classroom, FCM has replaced the traditional "spoon-feed" teaching mode with communication and sharing, which is undoubtedly beneficial to learners' ability of communication and collaboration. Therefore, FCM teaching has some practical values for cultivating students' cooperative ability, innovation ability and class unity.

\section{Acknowledgements}

Period results of the project: An Empirical Study of the Impact of Flipped Classroom on College Students' Autonomous Learning Ability, 2016 Higher Education Teaching Reform Research Project of Jiangxi Provincial Department of Education (project code: JXJG-16-102-2)

\section{References}

[1] Qi Ji. Researches on the Higher Vocational Teaching Mode Practice on the Basis of the Modern Apprenticeship SPOC Flipped Classroom[J]. Modern Professional Education 2017,12:70-72.

[2] Tan Yue, Tang Di. The Learners' Cultivation of Autonomy Based on the Flipped Classroom Teaching Mode [J]. Asia-pacific Education, 2015,29:280-281.

[3]Wu Lingjuan. Studies on the TED- Ed-based Universal Academic English Listening and Speaking Flipped Classroom [J]. E-education Research, 2015,11:81-87.

[4] Xu Xi. Cultivation of College Students' Autonomous Learning Ability in Flipped Classroom Mode [J]. Northern Literature (late), 2015, 05:217.

[5] Wang Na, Zhang Jingyuan. Design and Research on the College English Flipped Classroom Teaching Model Based on "SPOC + small classroom" [J]. China University Teaching, 2016,09:57-63. 